International Journal of Current Microbiology and Applied Sciences

ISSN: 2319-7706 Volume 10 Number 02 (2021)

Journal homepage: http://www.ijcmas.com

\title{
Economics of Gerbera Cultivation Grown under Polyhouse Conditions as Influenced by Foliar Application of Nano and Conventional Micronutrients (FE and $\mathrm{ZN}$ )
}

\author{
Devi Priya Avilala ${ }^{1 *}$, K. Swarajya Lakshmi ${ }^{1}$, T. N. V. K. V. Prasad ${ }^{2}$, \\ V. V. Bhaskar ${ }^{1}$, M. Ramaiah $^{3}$ and Lalitha Kadiri ${ }^{4}$
}

${ }^{1}$ Department of Horticulture, Dr. Y.S.R. Horticultural University, COH, Anantharajupet, Y.S.R. District- 516 105, A.P., India

${ }^{2}$ Department of Soil Science, Acharya N.G. Ranga Agricultural University, India

${ }^{3}$ Department of Entomology,

${ }^{4}$ Department of Agronomy, Dr. Y.S.R. Horticultural University,

COH, Anantharajupet, Y.S.R. District- 516 105, A.P., India

*Corresponding author

\section{A B S T R A C T}

Keywords

Gerbera,

Economics,

Polyhouse and Cost

of cultivation

Article Info

Accepted:

15 January 2021

Available Online:

10 February 2021
Benefit cost ratio is an important factor which decides the optimum level of inputs to be used for maximization of production and returns in any crop. In the present study, the benefit-cost ratio was worked out for different concentrations of nano and conventional micronutrients (Fe and $\mathrm{Zn})$ used in the study $\left(\mathrm{T}_{1}-\mathrm{Nano} \mathrm{ZnO} @\right.$ 300 ppm, T 2 - Nano ZnO @ 200 ppm, T T $_{3}$ Nano FeO @ 300 ppm, T 4 - Nano FeO @ 200 ppm, T $5^{-}$Bulk FeSO4 @ 0.2\%, T $6^{-}$Bulk ZnSO4@0.2\%, T $7^{-}$Nano ZnO @ 300 ppm + Nano FeO @ 300 ppm, Ts- Nano ZnO @ 300 ppm + Nano FeO @ 200 ppm, T $^{-}$Nano ZnO @ 200 ppm + Nano FeO @ 300 ppm, $\mathrm{T}_{10^{-}}$Nano ZnO @ 200 ppm+ Nano FeO@ 200 ppm, T 11 - Bulk ZnSO4@ 0.2\% + Bulk FeSO4 @ 0.2\%, $\mathrm{T}_{12^{-}}$control (Water spray)). The results revealed that $\mathrm{T}_{8^{-}} \mathrm{ZnO} @ 300 \mathrm{ppm}+\mathrm{FeO}$ @ 200 ppm recorded maximum net returns (lakh Rs. 93.82 ha $^{-1}$ ) with higher B:C ratio (1:3.68) whereas $T_{12}$ - control recorded minimum net returns (lakh Rs. 46.71 $\left.\mathrm{ha}^{-1}\right)$ with lower $\mathrm{B}: \mathrm{C}$ ratio $(1: 1.85)$.

\section{Introduction}

Floriculture is a fast emerging major venture in the world, especially as a potential moneyspinner for many third-world countries. Modern-day floriculture refers to the production of high-value cut flowers such as rose, gladiolus, carnation, gerbera, orchids, tuberose, anthurium, lilium, etc., Now a days, growing of these cut flower crops, suited for flower arrangements, decorations, for bouquets preparation and for floral baskets 
have increased substantially and its share of the total trade has also improved. India ranks second next to China under cultivation in floriculture with an area of 3.2 lakh hectares and produces 19 million tonnes of loose flowers and 8.2 million tonnes of cut flowers annually (NHB, 2018).

Many cut flowers and ornamental plants are being grown for domestic as well as for export market, provide more return per unit area than any other horticultural crops. Among cut flowers, gerbera currently ranks as the fifth most popular flower in the world after the roses, carnations, chrysanthemums and tulip.

Gerbera can contribute largely to floriculture industry by virtue of its yield potential, colour variation and long vase life. Cultivation of Gerbera under polyhouse has emerged as a very important option to progressive farmers in a many parts of India.

But farmers are facing some problems in gerbera cultivation such as environmental and technological changes, disease pest infestation and physiological disorders caused by micro nutrient deficiencies which reduces the quality, yield and ultimately the net returns. So commercialization of gerbera by using modern technologies will improve the cultivation condition and also enhances the quality and yields.

Recently, Nanotechnology is gaining a lot of importance and has been used in all stages of crop production. Foliar application of nano micronutrients also enhances the yield, quality of flowers and also gives higher benefit cost ratio. The main objective of the present study was to analyze the cost of production of gerbera grown under polyhouse as influenced by foliar application of nano and conventional micronutrients which was helpful to farmers in raising the net returns.

\section{Materials and Methods}

The experiment was carried out in naturally ventilated polyhouse located at floriculture block, College of Horticulture, Anantharajupeta, Dr.Y.S.R District. The frame of polyhouse was constructed with galvanized iron pipe with side and top ventilation, a rollable flap was provided on both sides of the polyhouse to regulate the requirements of temperature and humidity depending on the season and weather conditions. A uv-stabilised low density polyethylene film of 200 micron was used as cladding material. The sides of the polyhouse were covered with anti-insect proof rambonet of 60 mesh for natural ventilation and protection against insect pests. Manually operated 50 percent (white colour) shade net was provided inside the polyhoue to regulate the light intensity and temperature. To control the humidity in polyhouse the fogging arrangement was made by providing overhead foggers.

\section{Bed preparation and planting of gerbera}

The land was brought to fine tilth by ploughing up to $40 \mathrm{~cm}$ depth. Well decomposed farm yard manure, sand and coir pith in 2:1:1 proportion was added and thoroughly mixed with soil.

Fumigation was done by using formalin @ 810litres per $100 \mathrm{~m}^{2}$. Raised beds of $40 \mathrm{~cm}$ height, $70 \mathrm{~cm}$ width and convenient length were prepared with a walking space of $40 \mathrm{~cm}$ in between the beds. Gerbera plants (cv. Madagascar) was planted on beds by adopting a spacing of $30 \times 30 \mathrm{~cm}$. Basal dose of FYM @ $30 \mathrm{~kg} \mathrm{~m}^{2}$, single super phosphate (SSP) @ $2.5 \mathrm{~kg}$ per $10 \mathrm{~m}^{2}$ and magnesium sulphate $@ 0.5 \mathrm{~kg}$ per $10 \mathrm{~m}^{2}$ area on beds was applied before planting. After three weeks of planting water soluble fertilizers (NPK) 19:19:19 @ 1g per litre was applied through drip irrigation for first three months of planting. During 
flowering (NPK) 20:20:20 + 13:0:45 and water soluble fertilizers like Mono ammonium phosphate, sulphate of potash, potassium nitrate, calcium nitrate were given through fertigation for better flower quality. Need based plant protection measures were taken up to protect the plants from pest and disease incidence. Besides this, different concentrations of nano and conventional micronutrients ( $\mathrm{Fe}$ and $\mathrm{Zn}$ ) which includes $\mathrm{T}_{1^{-}}$ $\mathrm{ZnO} @ 300$ ppm, T2- $\mathrm{ZnO} @ 200$ ppm, $\mathrm{T}_{3}-$ $\mathrm{FeO} @ 300$ ppm, $\mathrm{T}_{4^{-}} \mathrm{FeO} @ 200$ ppm, $\mathrm{T}_{5^{-}}$ FeSO4@0.2\%, T6- ZnSO4@0.2\%, T 7 - ZnO @ 300 ppm+FeO@300 ppm, T $\mathrm{T}_{8} \mathrm{ZnO} @$ 300 ppm + FeO@200 ppm, T9- ZnO@200 ppm + FeO @ 300 ppm, T10- ZnO @ 200 ppm +FeO@200 ppm, T11- ZnSO4@0.2\%+ FeSO4@0.2\%, $\mathrm{T}_{12}$ - control (Water spray) were applied as a foliar spray at 45 days intervals from 30 days after planting.

The economics of gerbera cultivation in poly house was worked out for one year. Based on the yield data, the gross returns and net returns were calculated for each treatment. The benefit cost ratio $(\mathrm{B}: \mathrm{C})$ was determined by dividing the net returns with the total cost of each treatment on hectare bases. Cost of different concentrations of nano and conventional micronutrients was calculated separately with considering total material used.

The cost of cultivation in each treatment was worked out based on the actual expenditure incurred on each item. Only cost of each treatment is changing according to material used for the different treatments others costs are same.

The cost planting material, manures, chemical fertilizers, pesticides, fungicides, labour wages and all the cultural practices including harvesting was worked out based on the prevailing prices and wages during the cropping season and expressed as cost of cultivation per hectare.
Depreciation rate $(\%)=$ 100

Life span of an asset

Amount of Depreciation $=$ Cost of an asset $x$ Depreciation rate

100

\section{Gross income}

The gross income was calculated on the basis of sale price of gerbera stems prevailing during the study period. The total yield of gerbera cut flowers was multiplied with the average price prevailed in the market and expressed as total income per hectare.

\section{Net income}

Gross income minus cost of cultivation in each treatment was recorded as corresponding net income.

\section{Benefit cost ratio}

The ratio of net income to the total cost of cultivation was recorded as benefit - cost ratio. It was computed by dividing the net income by the total cost of cultivation.

Benefit cost ratio $=$

Net returns

Total cost of cultivation

\section{Results and Discussion}

The details of cost of cultivation, gross and net returns and benefit cost ratio of different treatments were presented in table 1 and 2. Depreciation cost for polyhouse construction, laying of drip and planting material was calculated for one year. There was significant differences among different treatments with respect to $\mathrm{B}: \mathrm{C}$ ratio. 
Table.1 Cost of cultivation of gerbera under naturally ventilated polyhouse (hectare ${ }^{-1}$ ) for one year

\begin{tabular}{|c|c|c|c|c|}
\hline S.No & Particulars & Details & Price Unit $^{-1}$ (Rs.) & Total (Rs.) \\
\hline A. & \multicolumn{4}{|c|}{ Fixed Cost } \\
\hline 1. & Construction of poly house & $\begin{array}{l}\text { Top: UV stabilized plastic sheets } \\
\text { Side: } 70 \% \text { Agro shade net (life span is } 10 \text { years) }\end{array}$ & $\begin{array}{l}\text { Rs. } 400 \text { /- per sq. mtr. } \\
\text { Depreciation @ } 10 \%\end{array}$ & $4,00,000$ \\
\hline 2. & Micro irrigation system & $\begin{array}{l}\text { Drip system for plants, misting system, } \\
\text { fertigation unit, water filtration unit (life span is } \\
10 \text { years) }\end{array}$ & $\begin{array}{l}\text { Rs. } 25 \text { /- per sq. mtr. } \\
\text { Depreciation@10\% }\end{array}$ & 25,000 \\
\hline \multirow[t]{5}{*}{3.} & Bed preparation & & & \\
\hline & 1.FYM & $30 \mathrm{~kg} / \mathrm{m}^{2}$ & Rs. $600 /$ - per tonne & 180,000 \\
\hline & 2. coir pith & $1 \mathrm{~kg} / \mathrm{m}^{2}$ & Rs. 5,000/- per tonne & 50,000 \\
\hline & 3. Basal dose fertilizers & $\begin{array}{c}\mathrm{SSP} @ 250 \mathrm{~g} / \mathrm{m}^{2} \\
\mathrm{MgSO}_{4} @ 50 \mathrm{~g} / \mathrm{m}^{2}\end{array}$ & $\begin{array}{l}\text { Rs. } 9000 \text { /- per tonne } \\
\text { Rs. } 9000 \text { /- per tonne. }\end{array}$ & 27,000 \\
\hline & 4. Formaldehyde & $\begin{array}{l}\text { Soil sterilization by formaldehyde @ } 7 \text { 1/100 } \\
\text { sq.m }\end{array}$ & Rs. 40 /- litre. & 28,000 \\
\hline 4. & Planting material & $\begin{array}{l}\text { Requires } 6 \text { plants per } \mathrm{m}^{2} \text { and } 60,000 \text { plants per } \\
\text { hectare (Duration of plants is } 3 \text { years) }\end{array}$ & $\begin{array}{l}\text { Rs.20/- @ each plant } \\
\text { Depreciation@33.3\% }\end{array}$ & $3,99,996$ \\
\hline B. & \multicolumn{4}{|c|}{ Variable cost } \\
\hline 1. & Irrigation charges & Including electricity charges & Rs. $4,000 /$ - per year & 4,000 \\
\hline 2. & Plant protection chemicals & Includes neem oil, rogor, fipronil, Blitox etc., & $\begin{array}{l}\text { Rs. } 0.20 / \text { - per plant per } \\
\text { month }\end{array}$ & 144,000 \\
\hline 3. & Fertilizers cost & $\begin{array}{l}\text { Includes calcium nitrate, potassium nitrate, } \\
\text { mono ammonium phosphate, sulphate of potash } \\
\text { and some micronutrients etc., }\end{array}$ & $\begin{array}{l}\text { Rs. } 0.5 / \text { - per plant per } \\
\text { month }\end{array}$ & 360,000 \\
\hline 4. & Labour cost & $\begin{array}{l}8 \text { labours daily for } 360 \text { days } \\
2 \text { men and } 6 \text { women labour }\end{array}$ & $\begin{array}{c}\text { Men@120 per day } \\
\text { Women@100 per day }\end{array}$ & 302,000 \\
\hline \multirow[t]{2}{*}{5.} & Packing and transportation & $\begin{array}{l}\text { This includes plastic sleeves, card board boxes, } \\
\text { transport and sales commision etc., }\end{array}$ & Rs. 0.20 per flower & $6,00,000$ \\
\hline & \multicolumn{3}{|c|}{ Total } & $3,320,000$ \\
\hline
\end{tabular}


Table.2 Economics of gerbera cultivation as influenced by nano and conventional micronutrients ( $\mathrm{Zn}$ and $\mathrm{Fe})$ production

\begin{tabular}{|c|c|c|c|c|c|c|c|}
\hline Treatments & $\begin{array}{c}\text { Fixed cost } \\
\text { (Rupees) }\end{array}$ & $\begin{array}{c}\text { Variable } \\
\text { cost } \\
\text { (Rupees) }\end{array}$ & $\begin{array}{l}\text { Total cost of } \\
\text { cultivation } \\
\text { (Rupees) }\end{array}$ & $\begin{array}{c}\text { Flower yield } \\
\text { ha }^{-1} \text { (lakh } \\
\text { number) }\end{array}$ & $\begin{array}{c}\text { Gross } \\
\text { returns } \\
\text { (lakh } \\
\text { rupees) }\end{array}$ & $\begin{array}{l}\text { Net returns } \\
\text { (lakh } \\
\text { rupees) }\end{array}$ & $\begin{array}{c}\text { Benifit cost } \\
\text { ratio }\end{array}$ \\
\hline $\mathbf{T}_{1}-\mathrm{ZnO} @ 300$ ppm & 1109996.00 & 1424400.00 & 2534396 & 35.07 & 105.21 & 79.87 & $1: 3.15$ \\
\hline$T_{2-}-\mathrm{ZnO} @ 200$ ppm & 1109996.00 & 1419600.00 & 2529596 & 32.41 & 97.23 & 71.93 & $1: 2.84$ \\
\hline $\mathrm{T}_{3^{-}} \mathrm{FeO} @ 300$ ppm & 1109996.00 & 1428000.00 & 2537996 & 32.90 & 98.70 & 73.32 & $1: 2.89$ \\
\hline 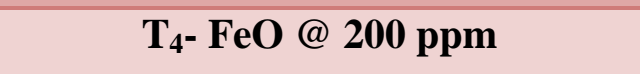 & 1109996.00 & 1422000.00 & 2531996 & 32.11 & 96.33 & 71.01 & $1: 2.80$ \\
\hline $\mathrm{T}_{5}-\mathrm{FeSO}_{4} @ 0.2 \%$ & 1109996.00 & 1417600.00 & 2527596 & 27.20 & 81.60 & 56.32 & $1: 2.23$ \\
\hline $\mathrm{T}_{6}-\mathrm{ZnSO}_{4} @ 0.2 \%$ & 1109996.00 & 1419600.00 & 2529596 & 27.69 & 83.07 & 57.77 & $1: 2.28$ \\
\hline $\begin{array}{c}\mathrm{T}_{7}-\mathrm{ZnO} @ 300 \text { ppm + FeO @ } 300 \\
\text { ppm }\end{array}$ & 1109996.00 & 1442400.00 & 2552396 & 38.40 & 115.20 & 89.68 & $1: 3.51$ \\
\hline $\begin{array}{c}\mathrm{T}_{8}-\mathrm{ZnO} @ 300 \text { ppm + FeO @ } 200 \\
\text { ppm }\end{array}$ & 1109996.00 & 1436400.00 & 2546396 & 39.76 & 119.28 & 93.82 & $1: 3.68$ \\
\hline $\begin{array}{c}\mathrm{T}_{9}-\mathrm{ZnO} @ 200 \text { ppm + FeO @ } 300 \\
\text { ppm }\end{array}$ & 1109996.00 & 1437600.00 & 2547596 & 38.19 & 114.57 & 89.09 & $1: 3.50$ \\
\hline $\begin{array}{c}\mathrm{T}_{10}-\mathrm{ZnO} @ 200 \mathrm{ppm}+\mathrm{FeO} @ 200 \\
\text { ppm }\end{array}$ & 1109996.00 & 1431600.00 & 2541596 & 36.17 & 108.51 & 83.09 & $1: 3.27$ \\
\hline $\begin{array}{c}\mathrm{T}_{11}-\mathrm{ZnSO}_{4} @ 0.2 \%+\mathrm{FeSO}_{4} @ \\
0.2 \%\end{array}$ & 1109996.00 & 1427200.00 & 2537196 & 30.70 & 92.10 & 66.73 & $1: 2.63$ \\
\hline $\mathbf{T}_{12-}$ control (Water spray) & 1109996.00 & 1410000.00 & 2519996 & 23.97 & 71.91 & 46.71 & $1: 1.85$ \\
\hline
\end{tabular}

*Cost of each gerbera stem- Rs. 3/- 
$\mathrm{T}_{8}-\mathrm{ZnO} @ 300 \mathrm{ppm}+\mathrm{FeO} @ 200$ ppm recorded maximum net returns (lakh Rs. 93.82 $\left.\mathrm{ha}^{-1}\right)$ with higher $\mathrm{B}: \mathrm{C}$ ratio $(1: 3.68)$ followed by $\mathrm{T}_{7}-\mathrm{ZnO} @ 300$ ppm + FeO @ 300 ppm (lakh Rs. 89.68 ha ${ }^{-1}$ ) with B:C ratio $(1: 3.51)$ and $\mathrm{T}_{9}-\mathrm{ZnO} @ 200$ ppm + FeO @ 300 ppm (lakh Rs. 89.09 ha ${ }^{-1}$ ) with B:C ratio $(1: 3.50)$ while $\mathrm{T}_{12^{-}}$control recorded minimum net returns (lakh Rs. $46.71 \mathrm{ha}^{-1}$ ) with lower B:C ratio (1:1.85). Similar trend of results were also obtained by Davarpanah et al., (2013) in pomegranate and Kumar et al., (2017) in strawberry.

Nanotechnology is one of the new technologies recently used in agriculture production. The researchers indicate many of the potential benefits of nanotechnology. Considering the present investigation, it may be concluded that foliar application of Zno @ 300 ppm and $\mathrm{FeO} @ 200$ ppm was found to be the best in terms of getting maximum benefits through cultivation of gerbera cut flower under naturally ventilated polyhouse.

\section{References}

Davarpanah, S, Mohammad, A, Mohammad, A.A, Babalar, M. and Mohammad, E.M. 2013. Effect of iron foliar application (Fe-Eddha) on quantitative and qualitative characteristics of pomegranate CV. Malas-e-Saveh. World of Sciences Journal. 2 (4): 179184.

Kumar, U.J, Bahadur, V, Prasad, V.M, Mishra, S. and Shukla, P.K. 2017. Effect of different concentrations of iron oxide and zinc oxide nanoparticles on growth and yield of strawberry (Fragaria $x$ ananassa Duch) cv. Chandler. International Journal of Current Microbiology and Applied Sciences. 6(8): 2440-2445.

NHB Data Base 2017-18 published by National Horticultural Board Department of Agriculture and Cooperation Government of India.

\section{How to cite this article:}

Devi Priya Avilala, K. Swarajya Lakshmi, T. N. V. K. V. Prasad, V. V. Bhaskar, M. Ramaiah and Lalitha Kadiri. 2021. Economics of Gerbera Cultivation Grown under Polyhouse Conditions as Influenced by Foliar Application of Nano and Conventional Micronutrients (FE and ZN). Int.J.Curr.Microbiol.App.Sci. 10(02): 1823-1828.

doi: https://doi.org/10.20546/ijcmas.2021.1002.215 